\title{
The effects of COVID-19 on vulnerable groups: A reflection on South African informal urban settlements
}

\begin{tabular}{|c|c|}
\hline $\begin{array}{l}\text { Authors: } \\
\text { Bethuel Ngcar } \\
\text { Evangelos Ma }\end{array}$ & $\begin{array}{l}\mathrm{mu}^{1} \text { (1) } \\
\text { ntzaris }{ }^{2}\end{array}$ \\
\hline $\begin{array}{l}\text { Affiliations: } \\
{ }^{1} \text { Department } \\
\text { Management } \\
\text { Faculty of Hur } \\
\text { Mandela Univ } \\
\text { Gqeberha, So }\end{array}$ & $\begin{array}{l}\text { of Public } \\
\text { and Leadership, } \\
\text { nanities, Nelson } \\
\text { ersity, } \\
\text { uth Africa }\end{array}$ \\
\hline $\begin{array}{l}{ }^{2} \text { Faculty of Ma } \\
\text { Studies, Mang } \\
\text { University of } \\
\text { Durban, South }\end{array}$ & $\begin{array}{l}\text { anagement } \\
\text { sosuthu } \\
\text { Technology, } \\
\text { ? Africa }\end{array}$ \\
\hline $\begin{array}{l}\text { Correspondin } \\
\text { Bethuel Ngcar } \\
\text { Bethuel.Ngcar } \\
\text { mandela.ac.za }\end{array}$ & $\begin{array}{l}\text { g author: } \\
\text { mu, } \\
\text { muza@ }\end{array}$ \\
\hline $\begin{array}{l}\text { Dates: } \\
\text { Received: } 13 \\
\text { Accepted: } 27 \\
\text { Published: } 29\end{array}$ & $\begin{array}{l}\text { Aug. } 2020 \\
\text { Aug. } 2021 \\
\text { Nov. } 2021\end{array}$ \\
\hline $\begin{array}{l}\text { How to cite th } \\
\text { Ngcamu, B., M } \\
\text { 2021, 'The effe } \\
\text { on vulnerable } \\
\text { reflection on S } \\
\text { informal urbar } \\
\text { Africa's Public } \\
\text { and Performar } \\
\text { a483. https://c } \\
\text { apsdpr.v9i1.48 }\end{array}$ & $\begin{array}{l}\text { his article: } \\
\text { lantzaris E., } \\
\text { ects of COVID-19 } \\
\text { groups: A } \\
\text { outh African } \\
\text { 1 settlements', } \\
\text { Service Delivery } \\
\text { nce Review 9(1), } \\
\text { doi.org/10.4102/ } \\
33\end{array}$ \\
\hline $\begin{array}{l}\text { Copyright: } \\
\text { @ 2021. The } A \\
\text { Licensee: AOS } \\
\text { is licensed un } \\
\text { Creative Comı } \\
\text { Attribution Lic }\end{array}$ & $\begin{array}{l}\text { Authors. } \\
\text { is. This work } \\
\text { der the } \\
\text { mons } \\
\text { cense. }\end{array}$ \\
\hline Read online: & \\
\hline 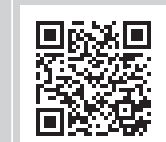 & $\begin{array}{l}\text { Scan this QR } \\
\text { code with your } \\
\text { smart phone or } \\
\text { mobile device } \\
\text { to read online. }\end{array}$ \\
\hline
\end{tabular}

Background: The economically vulnerable population, mostly black, especially those who are residing in precarious informal settlements are most susceptible to the coronavirus disease 2019 (COVID-19) pandemic.

Aim: To determine the impacts of the COVID-19 pandemic on the socio-economic condition of the vulnerable groups in South Africa. It also attempts to reflect the government's response strategies to provide help and services for the vulnerable communities who are considered to be most susceptible to the existing pandemic. Lastly, the response strategies of civil society groups and the challenges they are encountering in providing humanitarian assistance to indigent communities are explored.

Setting: This is a reflective study where secondary data has been analysed and intertwined with the researchers' experiences and insights of the South African informal settlements' welfare.

Methods: This article followed a reflective approach where the experiences of the vulnerable communities are strategically reflected upon.

Results: This fascinating study unearthed the effects of the coronavirus disease on the socio-economic conditions of vulnerable communities, the economy of the informal sector, the brutal enforcement agencies during the lockdown period, criminality, the fragmented government response and the marginalisation and frustration of civil society groups in providing humanitarian assistance to those in need.

Conclusion: The South African government's fragmentations, bureaucratic, maladministration and corruption in public departments have adversely impacted the welfare of the vulnerable groups who are living in the informal settlements. The human rights violations by the security agencies which are directed to the indigent people, and the centralisation of the humanitarian efforts by government had a negative effect on their wellbeing.

Keywords: civil society groups; coronavirus; food distribution; informal settlements; lockdown; police; SANDF.

\section{Introduction}

The outbreak of the silent killer coronavirus disease 2019 (SARS-CoV-2) was declared to be a public health emergency by the World Health Organization (WHO 2020c) on 30 January 2020, following this on 11 March 2020, confirmed it to be a global pandemic. This disease that emerged in the city of Wuhan in China has shaped the socio-economic conditions of both the developed and the developing worlds. The virus that increasingly spread throughout the developed nations, later reaching the African continent, is known to be susceptible to a myriad of risks that are mostly socio-economic. In South Africa, the National Institute for Communicable Diseases (NICD 2020) confirmed the first coronavirus disease 2019 (COVID-19) patient on 05 March 2020; 10-days later, the South African Government declared a national State of Disaster as per Section 27(2) of the Disaster Management Act, 57 (Act 75 of 2002). This was followed by the president's announcement of a 21-day national lockdown on 23 March 2020, which commenced on 26 March 2020. The National Coronavirus Command Council, dealing with mitigation and in response to COVID-19, developed a 5-level risk-adjusted strategy (from level 5 to 1). Level 5 was eased on 01 May 2020 (becoming level 4), which was further reduced to level 3 on 01 June 2020. Whilst on 02 June 2020, the Pretoria High Court (South Africa) declared levels 3 and 4 to be unconstitutional and invalid, as whilst there was 'rationality' in the state of disaster declaration, there were "'a number of 
regulations" that did not pass the "rationality test" of serving the stated goal of preventing the spread of Covid-19' (High Court of South Africa 2020).

In view of the above, the main purpose of this article is to evaluate the socio-economic conditions of the people who are living in the squatter settlements during the COVID-19 pandemic and how they could be adversely affected by the impacts of the pandemic.

This study therefore questions the extent to which the social conditions of vulnerable groups in informal settlements contribute to these communities being at a high risk of contracting the coronavirus. The shortcomings and challenges of government and its agencies as well as the response from civil society groups are questioned in this study.

The COVID-19 pandemic has been exponentially increasing in South Africa, with dire consequences for vulnerable groups. The hardest hit tends to be those in informal settlements.

Informal urban settlements are defined as densely populated urban areas with the characteristics of substandard housing and squalor (UN-Habitat 2007). Austrian et al. (2020) regarded people living in informal settlements as being vulnerable to infection by COVID-19, because of the shortage of basic needs including adequate housing, water, electricity and sanitation, and the fact that these areas are overcrowded. Favas, Checchi and Waldman (2020:4) showed that low-income countries (South Africa cannot be excluded) are particularly vulnerable to the COVID-19 pandemic as a result of the high nucleated population resulting in intense social mixing, increased urbanisation and much of the population residing in nucleated squatter settlements with inadequate sanitation. Favas et al. (2020:5) further advised that it is critical to recognise the roles performed by the civil society groups (including the nongovernmental organisations [NGOs] and community-based organisations [CBOs]) in squatter settlements. Lilford et al. (2016) suggested that almost 1 billion people in the world are estimated to be living in informal urban settlements and are highly susceptible to COVID-19 because of the inadequate provision of basic needs.

The poorest of the poor (those mostly living in informal settlements) have been hardest hit and severely affected by the restrictions because of their limited access to basic necessities and essential needs such as food, clean drinking water, sanitation and shelter. Previous claims have been supported by Corburn et al. (2020) who had shown that informal settlements are least prepared for the pandemic as a result of the inadequacy of basic needs - these include sufficient water, hygienic functioning toilets and sewers, adequate drainage, waste collection services and planned housing. The authors further explained that it is impractical to self-quarantine in such settlements because of space constraints, violence and overcrowding. In their policy study, Corburn et al. (2020) suggested that the government should avert the adverse consequences of COVID-19 in informal settlements by formulating emergency planning committees in such establishments, placing a moratorium on evictions, training and developing health workers and providing food assistance.

Against this background, the researchers of this article reflect on the social and economic conditions of the people who are residing in the squatter settlements in South Africa and their susceptibility to being affected and infected by the coronavirus. The government's response strategies in providing humanitarian assistance and the brutal approach of the security agencies (police and soldiers) during the lockdown period on vulnerable groups are also critically assessed in this article. Furthermore, the maladministration and bureaucratic practices in the distribution of food parcels and the marginalisation of civil society groups are examined.

\section{Research approach}

A content scientific and reflective analysis has been chosen as the basis of the present qualitative analysis utilised in the effort to dissect the effects of the COVID-19 pandemic on the social and economic conditions of the marginalised populations living in South Africa's informal settlements. The knowledge of the existing conditions in such establishments shaped the study and determined the reflective approach that led to the empirical cohesion and organisation. The identification of themes determined and identified the questions that were founded and shaped by the realities and challenges of the historical past and the everchanging present.

The undertaken content analysis based on the qualitative paradigm was founded primarily but not exclusively on the language-based characteristics of communicative patterns and was focused primarily on the realities of the COVID-19 content and its direct and indirect effects on the economic and social circumstances of people and businesses in the informal settlements. The electronic text-based data were coded through the utilisation of the NVivo software programme. This led to thorough content analysis that culminated into the creation of categories rooted on the text data (Bryman 2014). The choice of a thematic analysis was founded on the fact that the themes and patterns emerging from the data, and the analysis and dissection that follows is a new contribution to the knowledge based on a carefully chosen empirical process leading to a clear understanding and interpretations of the features of COVID-19 and its effects (Braun \& Clarke 2006).

\section{Background to COVID-19 in South Africa}

During the initial stages of the coronavirus, internationally, many governments were ready to face the COVID-19 pandemic. There were, however, very few reported cases in South Africa and Africa. This is despite the fact that over the years South Africa has faced a very serious burden of communicable and non-communicable diseases, together 
with a public healthcare system that has for quite some time been resource-constrained for a variety of reasons including high levels of corruption.

The first COVID-19 case in South Africa was confirmed on 05 March 2020 (ICD 2020). A traveller flying from Italy to Johannesburg was the first carrier of the virus. The second case appeared in early March in Cape Town. Here again, the patient was a traveller who had visited three European countries and Turkey (Parker et al. 2020:464). By 15 March 2020, there were 51 infections in South Africa. The immediate action of the country's President included a national State of Disaster as well as a thorough screening of all overseas travellers.

Following the first reported cases, mostly emanating from international travel, and with the evidence of community spread for the first 3 weeks (reaching 274 positive cases and no fatalities), the government announced a countrywide lockdown from 26 March 2020 to midnight of 30 April 2020 (from the first four weeks, later extended to six). At the time, there were many questions throughout the country regarding the future of the disease, given the WHO's grim predictions for the virus (WHO 2020a, 2020b) and its effects especially amongst the poorer populations globally as well as in countries with unsatisfactory or inadequately sourced healthcare sectors. The WHO's predictions and calculations, based on strict scientific research findings, remarked that most African countries needed to be extremely careful: They and their healthcare systems were poorly resourced and inhibited by a very diversified and sizeable poor and marginalised population that for many years had a noticeable vulnerability to epidemics (Talisuna et al. 2020). Despite South Africa being considered to be in a relatively better financial and social situation in comparison to most other countries in sub-Saharan Africa (SSA), there are a number of realities confirming the existence of poverty such as hunger, high unemployment rates, poor health and lack of basic necessities such as homes, water and sanitation for the majority of the country's population in particular the millions living in its informal settlements (Plagerson \& Mthembu 2019). The Studies on Poverty and Inequality Institute (2017) had revealed that the housing crisis in South Africa is evident at the latest data from Statistics South Africa (StatsSA) General Household Survey pinpointing that $79.3 \%$ of households in South Africa live in formal dwellings, while $13.9 \%$ of households live in informal dwellings and $5.9 \%$ of households live in traditional dwellings. The figures show that by the end of 2016, approximately 1 in 7 South African households lived in informal settlement. It has been shown that the figure is much higher in urban areas, where one in every five households lived in an informal dwelling.

The lessons learnt from the severe devastation of epidemics such as human immunodeficiency virus (HIV) infections, deaths from acquired immunodeficiency syndrome (AIDS) and tuberculosis, in addition to high numbers of diseases such as diabetes, hypertension and cardiovascular disease point to a very difficult and extremely challenging road ahead (Mayosi \& Benatar 2014). The signs indicate that large sectors of the country's population are at a high risk.

\section{The pandemic's effects on the country and socio-economic conditions}

For the last few months, the situation in South Africa and SSA has shown that the pandemic has been responsible for a high number of deaths. It has brought major disruption to most economic activities on the subcontinent, and indeed in the whole world. The latest predictions from the World Bank related to the SSA economy after the pandemic indicate that the region will face its first recession in 25 years; economies could shrink by as much as 5.1\%. World Bank Report (2018) of 'a severe food security crisis' was based on the reality that as agricultural production, distribution and imports have fallen, the future does not look promising for this agriculture sector. This will be connected to the negative impact of the virus on the continent's and South Africa's most important trading partners and in fact the whole world (World Bank in Africa 2020).

The predictions of the World Bank indicate that South Africa, Angola and Nigeria are the economies that will suffer most as a result of the pandemic as they are dependent on the export of oil and other minerals. It was also reported that a number of countries, including South Africa, will face such realities because of the implementation of protracted lockdowns aimed at controlling the virus's spread (World Bank in Africa 2020). The latest African Union (AU) world research report calculated that almost 20 million jobs on the continent may be threatened (African Union 2020). Inevitably, the present and future negative impact of the COVID-19 crisis on household welfare, especially amongst large groups of the poor, homeless and marginalised, will be equally dramatic.

This means that African politicians and continental policymakers need to play a key role in developing strategies that target two fundamental objectives: saving lives and protecting as many livelihoods as possible. Such strategies include recovery and relief measures that primarily aim at strengthening existing health systems, offering tangible liquidity support to viable businesses and providing income support to workers, the poor and vulnerable communities. It is understood that continuous financing to the social groups in need as part of these policies faces a number of serious challenges because of a deterioration in fiscal position and present and future public debt vulnerabilities. Therefore, inevitably, the African countries will be forced to seek assistance in the form of finance, including debt service and COVID-19-related multilateral assistance, from their development partners.

\section{Financial injection}

Calderon et.al. (2020) in their thorough analysis of issues that are and will be shaping Africa's economic future had indicated that for the recovery of SSA, an economic stimulus of as much as $\$ 100 \mathrm{~b}$ ( $£ 80 \mathrm{~b}$ ) could be needed. It was also 
recommended by the authors that the strengthening of the health systems in SSA would be a key priority, together with debt relief. In addition, initiatives are needed to develop policies that streamline efforts to support the vast numbers of people who are at present employed in the informal sector and lack access to insurance (Calderon et.al. 2020).

The existing financial projections regarding South Africa point to a continuous crisis in the country's economy, mainly because of the pandemic. Accordingly, whilst Statistics South Africa (StatsSA) had predicted a pre-COVID-19 growth rate of $0.2 \%$ in 2019 , the forecast of the International Monetary Fund (IMF) gives a contraction of up to $5.8 \%$ in 2020. The South African Reserve Bank (SARB) anticipated negative growth of $7 \%$ for 2020. Meanwhile, the Bureau of Economic Research (BER) attached to the University of Stellenbosch anticipated a contraction of $15.8 \%$ in the country's gross domestic product (GDP) for the second quarter of 2020 as compared to the previous year, with household consumption declining by $7 \%$ in the current year (Talisuna et al. 2019).

Without doubt, such macroeconomic predictions, should they become a reality in the coming months, will exacerbate South Africa's current unemployment and massive starvation crisis, with the IMF predicting a massive increase in unemployment of more than $35 \%$ in 2020. The recent calculations by Stats South Africa (2021b) have shown that the 'expanded unemployment rate' that incorporates the discouraged work seekers including those who have not searched for work because of a number of causes has been elevated from $42.6 \%$ to $43.2 \%$ (Stats South Africa 2021a). The BER, however, believes that such estimates are based on conservative calculations, given unemployment data from other countries (Centre for Risk Analysis 2020).

\section{Economic impacts of the lockdown on local economy and vulnerable groups}

The entire population of South Africa has been responsive to academic, intellectual, political and ideological ideas, and peoples' articles, opinions and predictions have found most citizens in a debating mood. This is the case even when people are confined to a luxury apartment in Cape Town's Camps Bay, a 10-bedroom house in Johannesburg's Houghton, a $7 \mathrm{~m} \times 8 \mathrm{~m}$ shack in Durban's Banana City informal settlement or government subsidy house (commonly known as Reconstruction Development Plan [RDP] house) in Cape Town's Khayelitsha Site B (Schmidt et al. 2020).

Discussions have carried on unabated, yet the realities of hunger amongst the masses of the vulnerable poor have increased dramatically. This is primarily because the prices of food over the years, especially from the first quarter of 2018 when value added tax (VAT) increased to $15 \%$, has increased substantially. A household affordability index released in mid-2018 showed conclusively that families could not afford to eat properly. A lack of proper nutrition would be a major barrier to the country's and especially new generations' developmental outcomes, principally those related to education. It was stated that when hunger is prevalent amongst poor and vulnerable communities, the health sector would be in serious danger of collapsing. This according to the Household Affordability Index (Pietermaritzburg Economic Justice and Dignity 2018) meant that child stunting at the time stood at $25 \%$ for girls under the age of five years and at $30 \%$ for boys under the age of five years. A situation like this continuing without intervention would be to the detriment of families and the country as a whole (Pietermaritzburg Economic Justice and Dignity 2018).

The household index also showed that the average disadvantaged family was forced to cut down on nutritious food by as much as $26 \%$; they could only afford to purchase nutritional food with an extra R1062.38 per month. It further showed that the cost of food in a poor household was R3009.65 per month. At the time it was reported that black South African households were expected to survive with a R3000 median wage (Pietermaritzburg Economic Justice and Dignity 2018).

In 2019, working class and vulnerable families faced an even worse situation as electricity and transport costs increased substantially, resulting in these groups spending at least $24 \%$ less on groceries. Empirical research indicated that electricity and transport costs accounted for $58.7 \%$ of the budget of low-income households. Such a figure is related to households with an average monthly income of R3024. Electricity and transport are non-negotiable expenses for the poor and vulnerable in South Africa (Pietermaritzburg Economic Justice and Dignity 2019).

Whilst the government accepted the proposal of an average price increase of $15.63 \%$ in electricity for municipalities as proposed by the national energy foundation of the country (NERSA), the petrol price also increased by $9 \%$. This meant that the local taxi fair, the main public transport for the poor, workers and sections of the middle class increased by almost $8 \%$, with electricity going up by $13.07 \%$ (Pietermaritzburg Economic Justice and Dignity 2021a). These increases meant that after paying for electricity and transport, these social groups were left in a situation where all key essentials in a household would be secured with R1249.48. At that time, in 2019 , the cost of nutritional food for a basic family of four was R2318.97 (Pietermaritzburg Economic Justice and Dignity 2021b).

Such conditions seem almost good when compared to those families who live on the wide variety of government grants for children, the elderly and those with disabilities. In terms of numbers, millions of South Africans of all ages depend on social grants in order to survive each month, many of whom fight hunger every day.

The 2020 pandemic has been instrumental in aggravating such realities amongst the poor and vulnerable but has also had negative effects on many aspects of governance operations, which have led to a lack of trust in government. This is because governments and their associated mechanisms 
throughout the world have utilised the present circumstances to their benefit by expanding their executive powers and restricting the rights of individuals at a number of political and societal levels.

South Africans' main concern is regarding the long-term economic impacts of the COVID-19 pandemic. A total of $67.7 \%$ of the respondents of a survey conducted by StatsSA confirmed this as opposed to $12.3 \%$ who were concerned about the short-term effects (Githahu 2020).

The same media article pinpointed that $8.1 \%$ of the interviewees were forced to close their businesses or lost their jobs. It was shown that $1.4 \%$ had joined the unemployment queues although $60.5 \%$ could potentially return to their employment (GitHub 2020). A host of commentators (Jarvis et al. 2020) have recorded the pandemic as subsiding in developed countries such as China and Sweden, with other authors (Dehab et al. n.d.) suggesting that measures to increase restrictions in informal settlements would be physically unfeasible as it would disrupt the economy and people's livelihoods.

\section{Enforcements and police brutality}

It has been reported that in South Korea and Israel, for example, governments have violated basic human rights by using smartphone location data to track down citizens suspected to be infected. Singapore performs extensive contact tracing and immediately makes public the detailed information of all new cases. The Singapore Department of Health makes public announcements through all media, printed and social, regarding the conditions in meticulous detail at all societal levels, hospitals, clinics and communities (Singapore Department of Health 2021).

In India, the government has pressurised the country's media to maintain positive coverage, whilst it has implemented disturbing strategies such as requiring individuals kept in quarantine to upload 'selfies' whilst using location tracking to ensure that the photograph is taken at the individual's home. The attempts of the government to cover up the non-existing mitigation of the wide spread of COVID-19 in cities such as New Delhi and Mumbai were notified within all sections of the country's communities. Wide coverage of the situation put a spotlight on the health crisis in India and the political, social and economic aspects of COVID-19, a real humanitarian crisis in the country (DW 2021).

In a number of countries, including Iran, South Africa, Israel and Peru, the military has been used to enforce lockdowns, in addition to keeping 'law and order' (Brown, Brechenmacher \& Carothers 2020). In South Africa, it is clear that public trust has turned against the government, because of the presence and behaviour of both the police (the South African Police Service [SAPS]) and the army (the South African National Defence Force [SANDF]), exacerbated by the hunger of the poor, vulnerable and marginalised. Consequently, during the second day of the lockdown, on 28 March 2020, police and army soldiers used rubber bullets against a crowd of 200-300 in order to disperse them. This took place outside a popular supermarket in the Yeoville area of Johannesburg's central business district. One day before this event, soldiers covering their faces with masks and wearing gloves patrolled Alexandra, a predominantly working class black African township in Johannesburg North. They arrested 55 people who 'were not staying at home as they should', according to the Minister of Police (Burke 2020).

As time passed, South Africa's very strict lockdown was considered successful both nationally and internationally, with a reduction in the average daily increase of confirmed coronavirus cases from $42 \%$ to about $4 \%$. The poor, vulnerable and homeless mainly survived because of the selfless support of food parcels donated throughout the country by philanthropic organisations and neighbourhood support groups. The Government of South Africa, in one of the world's most unequal societies, shut down almost all commercial activity throughout the country, an action that has mainly hurt the poorest of the poor and those who are most vulnerable. Before the generous humanist approach by support groups became more prevalent, most of the poor and homeless survived by digging through garbage and collecting plastic, glass and recyclable materials and selling them to recycling centres and small, privately owned companies.

In contrast, there has been strong evidence that the continual problems faced by the poor and vulnerable and the sometimes heavy-handed behaviour of the police and the army - mainly against the poor - has resulted in negative attitudes towards the government, which took a number of different forms. On the eighth day of the lockdown (03 April 2020), the country's Independent Police Investigative Directorate (IPID) initiated the investigation of eight deaths involving the police from the first day of the lockdown (Nyathi 2020).

The country's National Editors' Forum in an open statement expressed serious concern over the police action, which denied the media access to sites when attempting to cover COVID-19-related stories (News24 2020).

The 'highly militarised' and 'heavy-handed' actions of the police and army in the enforcement of lockdowns in a number of countries, including South Africa, were seriously criticised by the Office of the United Nations High Commissioner for Human Rights on 27 April 2020 (Al Jazeera 2020; Evans 2020). In the first three weeks of the lockdown in South Africa, a total of five fatalities and 152 assault incidents by police were recorded (Nyathi 2020).

\section{The COVID-19 pandemic and criminality}

One of the most disturbing issues that surfaced during the lockdown was the news that gender-based violence had increased by 2.300 per week that led to the arrest of 148 suspects in mid-April. In one case, a police officer dealing with a domestic violence case in Johannesburg was shot dead 
by a man who then committed suicide. Soldiers and police were accused of brutality by African township residents as they tried to enforce the lockdown. In Alexandra township, a man died after soldiers found beer at his home and, after accusing him of violating the lockdown, beat him, leading later to his death. It was announced that the army was investigating the incident (Star Advertiser 2020).

On the same day, the looting of supermarkets and closed liquor stores continued throughout the country.

Criminals and community members participated in 21 recorded incidents of looting and burglary in Cape Town alone from the time the lockdown started, whilst there were many other cases of attacks that have not been recorded by the police. During this period, 21 suspects were arrested. The attacks took place in Tafelsig, Heideveld, Athlone and Gatesville, all of them predominantly coloured areas. In general, it was the liquor stores that were targeted for attacks and looting, in particular in Cape Town, beginning in the last week of March. This is possibly because such shops had not been allowed to operate during the lockdown as they were considered to be an integral part of the social distancing regulations.

The existence of criminal gangs in the areas where these attacks took place points to the fact that thirst crime is the primary reason for such attacks despite the danger of facing criminal charges. The mere fact that similar and even more violent attacks took place in areas such as Langa (a predominantly African township) and Diep River points to the strong possibility that these acts were rooted primarily, if not exclusively, on negative attitudes against the provincial government (the Democratic Alliance [DA], the country's official opposition party that controls the Western Cape), the national government or both. On the same night of the attacks against liquor stores, the country's minister of police announced that four police officials were detained for illegally selling liquor (Breakfast 2020).

\section{Food distribution debacle and municipal councillors' interference}

The COVID-19 pandemic has had detrimental effects on vulnerable groups who are mostly living below the poverty line. These vulnerable groups include women, children, the aged and those living with disabilities - people who are mostly indigent. These citizens survive through the distribution of food parcels by civil society groups, which are not adequate for the daily survival of the families. The vulnerable groups who depend on sometimes sporadic donations through food parcels tend to be child-only households. In South Africa (2018), there were approximately 55000 families living in a total of 33000 child-headed households, which equates to $0.3 \%$ of child population (Hall 2019). Francis and Webster (2019) regarded South Africa as a paradox as it is considered the most unequal country in the world, with a 0.63 Gini coefficient and many of its citizens living in poverty, with economic growth stagnating and inflation remaining high despite its progressive constitution.
This is evidenced by an extremely high unemployment rate of $27.32 \%$ (Plecher 2020).

The government's response to address hunger during the COVID-19 lockdown has been considered to be inadequate. A total of $55 \%$ of the population in South Africa live under the poverty line, as shown by the StatsSA poverty line of R1267 per person per month (in 2020 rands). Yet, R50 billion is allocated to social grants - a tenth of the total economic relief percentage of R500b (Corruption Watch 2020). Prior to the pandemic, Oxfam South Africa estimated that 13 million people are experiencing hunger and malnutrition.

The largest survey performed by the Human Sciences Research Council (HSRC) of South Africa (with 20000 respondents) revealed that $24 \%$ have no money to buy food, and more than half the population resides in informal settlements and in townships.

Poverty has also been noticed in gang-ridden and dangerous suburbs in coloured and black African areas. Such locations are usually notorious and infested with heartless gang members. However, the warring gangs united against poverty in Manenberg on the outskirts of Cape Town during the pandemic. These gangs worked side by side, providing humanitarian services to communities by distributing food in the form of bread, flour and vegetables to poor and struggling families during the lockdown (Imray 2020). Conversely, the mayor's office in the City of Cape Town opposed such a gesture as it regarded these gangs' core business to be associated with murder, drug smuggling, gun trafficking and extortion, in addition to corrupting the police and judges.

Complaints in the West Rand were made against a local councillor who interfered with the distribution of food parcels to needy residents that were donated by Deep Education and Community Trust (Gold Fields). This has been disputed by the Member of the Mayoral Committee (MMC) for Social Development and Health in the Rand West City Local Municipality, declaring that the councillor did nothing wrong - there were too many needy people against a low percentage of middle class residents and the matter had been aggravated by political infighting in the area (Dlamini 2020).

A study commissioned and compiled by the World Bank (2018:1) found that:

South Africa is the most unequal state in the world, with $1 \%$ of South Africans owning $70.9 \%$ of the country's wealth, while the bottom $60 \%$ controls only $7 \%$ of the country's assets. The World Bank (2018) reported that black South Africans, the unemployed, the illiterate, female-headed households, large families and children are the groups most affected by poverty. Statistics South Africa (2019) recorded an increase in unemployment, from $27.6 \%$ in the first quarter of 2019 to $29 \%$ in the second quarter of the year. Furthermore, the income inequality of the labour market is $74.2 \%$, with the female workforce earning approximately $30 \%$ less than their male counterparts. In addition, poverty is widespread in the former 'Bantustans' (rural areas) and in informal settlements. 
Meanwhile, the Human Settlement Ministry has identified five informal settlements whose inhabitants have been requested to relocate as concerns grow in terms of the spread of COVID-19 in the densely populated informal settlements. These conventional settlements include two townships in Gauteng in Alexandra, Mooi and Dunoon townships in the Western Cape, the popular Kennedy Road settlement in Durban and Duncen Village in the Eastern Cape province (Mahlati 2020). There have also been attempts to include the NGOs in relocation plans and strategies although such organisations are excluded in the distribution of basic necessities to the poorest of the poor by government agencies and its officials. This is happening although NGOs are the first ones to respond to humanitarian crises in settlements during or after disasters. There are 22000 NGOs registered with the Department of Social Development, with a host of CBOs that perform important development, humanitarian and advocacy functions in South African society (Barnard 2020). They have played a tremendous role in providing humanitarian assistance to millions belonging to vulnerable groups adversely affected by the COVID-19 pandemic. Nonetheless, there are initiatives during this trying period that seek to assist NGOs in order to provide services to the marginalised communities in the country. For instance, emergency funding operations have been launched by a large number of organisations such as Charities Aid Foundation (CAF) South Africa (CAFSA) and Gap Fund (Mergon Group). The organisation CAFSA manages emergency funding for the Oppenheimer Generations Foundations and the National Lotteries Commission (NLC).

\section{Government COVID-19 response to vulnerable groups}

The COVID-19 pandemic has exposed the deep-seated inequalities in the country in terms of access to sufficient and nutritious food by the vulnerable and poor people. The people most affected by the existing realities are predominantly black South Africans, women, children and the elderly and the homeless. The access to sufficient food by marginalised communities has been hampered by government's ineffective, inefficient and corrupt organs of state during this punitive and ill-informed lockdown.

The lack of access to sufficient food by the indigent and marginalised communities in South Africa has destroyed or lowered their quality of life and has further increased food insecurity. Moreover, their constitutional rights as per Section 27(1)(b) of the Constitution of 1996, which states that every citizen has the right to access sufficient water and food, has been violated (Pillay 2021).

The state has further exposed these communities; they have been severely affected and infected by this virus because of the unavailability of clean and potable water in hazardous residential areas. South Africa is a water-scarce country, which in the recent past has been prone to reduced and recurring droughts. This reality has been echoed by Engineering News (2020), which indicated that the country has been susceptible to extreme water scarcity since 2014, with the resultant water restrictions still in place in many parts of the country. This stance is supported by the Budget Justice Coalition (BJC), which has described the economic measures implemented by government during the lockdown as punitive to the working class, the poor and the marginalised in the country including women, children and foreign nationals (Corruption Watch 2020).

The above realities shed light on the fact that the majority of the poor will be affected by the coronavirus as water scarcity in their areas increase the probability and propensity to be infected by the virus.

\section{The politics of the food parcels}

Food parcels are normally given by local government councillors to the poor; such parcels generally include maize meal, rice, cooking oil and other basic necessities. Councillors are responsible for identifying households that are in dire need of these food parcels although the donors themselves are often marginalised during the actual distribution. These donations open up the corrupt tendencies of some councillors who distribute food parcels based on political partisanship or to their friends and family members. On many occasions, they have denied altogether that such donations exist, keeping them for themselves. This has been reported in various newspapers describing how and when councillors, mostly from the ruling party (the African National Congress), have been linked to corruption and looting of food parcels during lockdown in different provinces, instead of distributing food to the vulnerable communities they are intended for (City Press 2020).

The councillors in South Africa are known for their corrupt tendencies. For instance, on 11 December 2019, the Mercury Newspaper reported that the Directorate for Priority Crime Investigation arrested 15 eThekwini Municipality officials for fraud-related matters, and councillors were amongst them. Accordingly, Ngamlana (2020), writing in the Sunday Independent, argued that the food parcel distribution during the lockdown has exposed the systemic and systematic problems in municipalities, even though the initiative was a proactive response strategy initiated and guided by the national government. The author disclosed that reports on the municipal councillors hoarding or selling food parcels have surfaced, whilst outwardly these councillors are regarded as having the best interests of their constituents at heart. Another newspaper (Ngamlana 2020) reported that the trust between the municipal councillors and their constituents is at its lowest. Residents rely on local politicians to compile a list of the indigent as the municipality does not have a credible and accurate database that captures the socioeconomic profile of households at a ward level, providing a base for service delivery decisions.

The distribution of the food parcels (Figure 1) has been marred by the ruling political party's government-based bureaucratic processes and systems, whilst people are going 


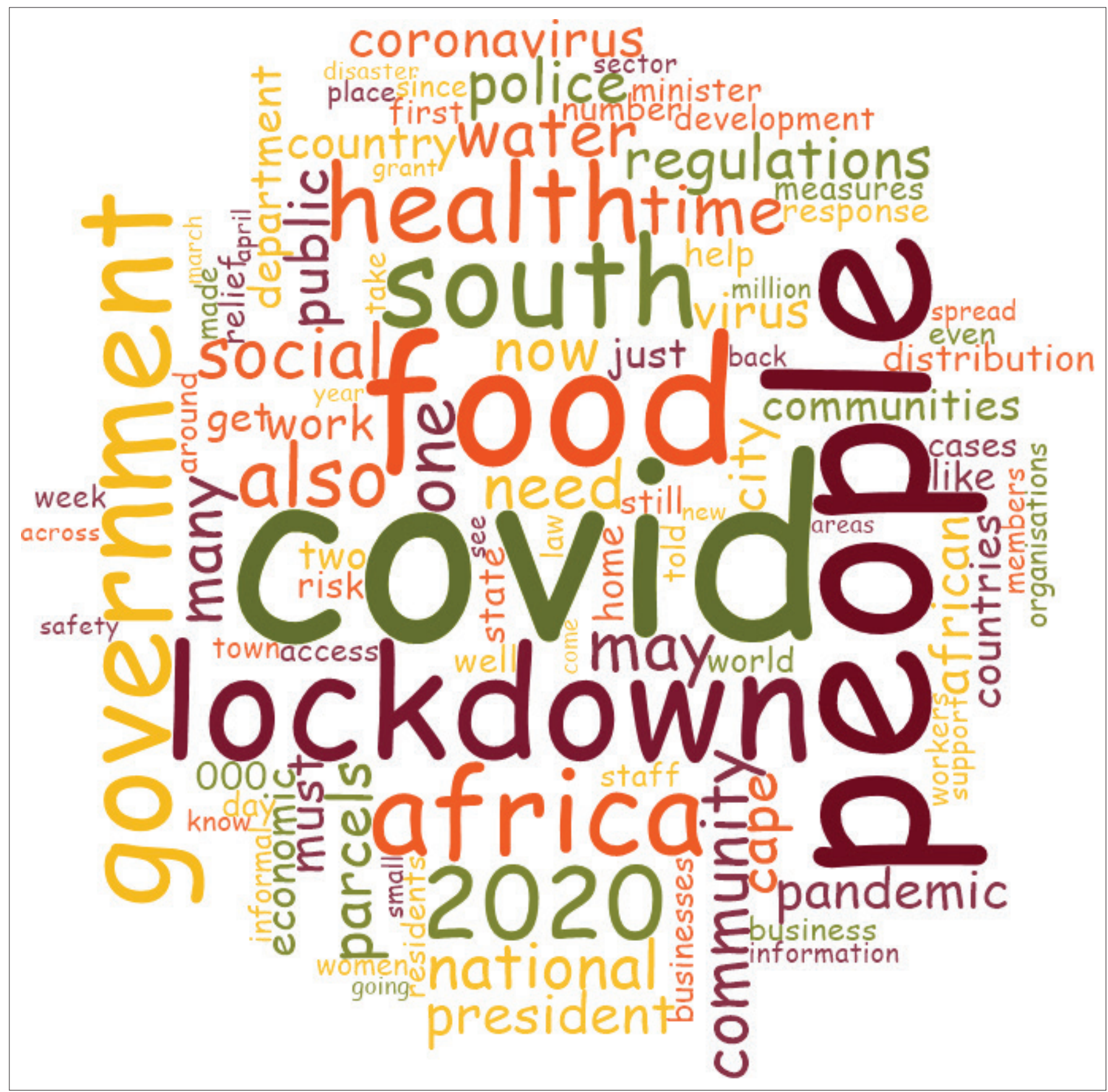

FIGURE 1: Food parcel distribution.

to bed on an empty stomach on a daily basis during the lockdown. Apart from the bureaucratic distribution processes of the food parcels to indigent communities (mostly black urban and rural residents), the lockdown itself has been considered by a host of commentators to be cumbersome and inconsistently implemented from municipality to municipality.

Furthermore, the centralisation of the distribution of the food parcels has triggered anger from the poor who have been waiting for a long time for such parcels as well to hear from political parties. An outcry from society mostly stems from the high level of distrust citizens have for the political and administrative leadership. However, this lack of trust from different stakeholders has been echoed by the president of South Africa (eNCA 2020), who was quoted on local television saying that: 'We are deeply disturbed by reports of unscrupulous people abusing the distribution of food and other assistance for corrupt ends'.

The widely reported bureaucratic operations of South African Government departments have been experienced in the small Eastern Cape town of Cradock, where the local Spar donated 300 food parcels for distribution to the needy. These parcels languished in a local community centre as they did not meet the regulations of the South African Social Security Agency (SASSA) in terms of quantity. The Spar store then teamed up with an association of local foreign-owned 
shops that did meet the SASSA requirements and they were finally able to distribute the food to needy communities (Davis 2020a).

The leading opposition political parties (the DA and the Economic Freedom Fighters [EFF], amongst others) in South Africa have also rejected the centralisation of the distribution of food parcels mainly through the Social Development Department by claiming that the government's approach is inefficient, interfered with by politicians and regarded as a gateway to corruption. The EFF released a well-publicised critique of what was described as the unfair distribution of food vouchers, suggesting that the smart vouchers and cash transfers be used for recipients who are already in the SASSA database. Such an initiative, the party indicated, would be instrumental in not only reducing the existing and perpetual corruption but would also ensure that the relief measures would reach the legal and intended beneficiaries timeously. Such a process, the EFF believed, would guarantee that the distribution system for food parcels during the lockdown period would be transparent. In contrast, the party indicated its sadness in response to what it called the 'sporadic community-based protests' over food parcels, which occurred in a number of areas in the Gauteng province, in particular those that took place in the Booysens squatter camp. The EFF's Gauteng branch warned the ruling party that the manipulation of the distribution of food parcels by ANC councillors - who benefitted only supporters of their organisation - needed to be stopped immediately; this was a ticking time bomb, sowing divisions within communities (Parliamentary Monitoring Group 2020).

The civil society groups including NGOs, non-profit organisations (NPOs), CBOs and local businesses, which have been praised for responding effectively and efficiently to both slow and fast onset of disasters, have been frustrated by the government's bureaucracies and fragmentations in the distribution of food parcels. In countries such as Bangladesh, Ahmad (n.d.) had highlighted the fact that there were NGOs who had consulted the government to work in collaboration with them. These NGOs have partnered before at grassroots level, focussing on disaster management. Such groups in South Africa have been met with resistance from the provincial Members of the Executive Council (MECs) and mayors. Political leaders have complained that such civil society groups are contravening the regulations regarding food distribution during the lockdown period (NGOPulse 2020; Parliamentary Monitoring Group 2020).

The NGOs, such as the Gift of the Givers, Rise Against Hunger, Feed South Africa, Helping Hands, Angel Network, and UNICEF South Africa, in particular those with a reputable record in responding to disasters, have been frustrated by government's red tape when applying for permits to distribute food parcels. There are also NGOs such as Solidarity Helping Hand, which have a national permit but are frustrated by government's centralisation strategy.
This was confirmed by an NGO's representative to the media, who said that:

Helping Hand has national permits in place, but now government seeks regional and municipal permits as well and it seems the state's regulations differ from place to place, adding to [the] confusion. The civil society groups can't allow these uncertainties to interfere with their mission to alleviate poverty and hunger (Davis 2020a:1).

The NGOs in particular have a long history and much experience in working with indigent communities; they understand the conditions, those who are in need and those who are food insecure. This has been supported by Macarthy et al. (2017) who believed that there are pre-existing NGOs who are skilled in disaster prevention and response. The donors in South Africa trust these NGOs more than the government (because of the rampant corruption) and have provided them with funds for humanitarian purposes. For instance, Corburn et al. (2020) cited many examples of the crucial role and engagement played by different organisations, including NGOs, faith-based organisations and CBOs in response to the COVID-19 pandemic. Meanwhile, the NGOs have views regarding the centralisation of the distribution of food parcels. This was exemplified by Davis (2020b:1), who wrote that:

I've spoken to people from within the NGO sector ... they feel that government essentially wants to take the glory (of any food distribution) for themselves. The reason they want to centralise it is so that people are quite clear who's giving them food, and come election day they will remember that.

The NGOs do not provide humanitarian assistance in the form of food to canvass for votes; rather, their motive is to aid the poorest of the poor and to be accountable to their donors.

\section{Conclusion}

This reflective study explored and espoused the effects of the COVID-19 pandemic on vulnerable communities that are mostly living in informal settlements. The government's fragmentations and bureaucratic processes have had adverse effects on designated groups and have hindered the concerted efforts by different stakeholders, including civil society groups. These defenseless individuals mostly living in informal settlements are significantly affected by the pandemic. The COVID-19 adverse effects on vulnerable groups have been attributed to the South Africa's long history of inefficiencies and corruption, which have paralysed the healthcare system. The pandemic has exposed many of the country's weaknesses and is having disastrous impacts on vulnerable groups.

The effects of COVID-19 have been linked to a multiplicity of factors including increasing food insecurity, weakening of the economy, rising unemployment rate and the compromising future sustainability of the informal sector. The effects on vulnerable groups have been also linked to a lack of proper nutrition, increased electricity prices and a low quality of life.

The coronavirus and the associated lockdown brought back to South Africa the brutality of the apartheid police, which is 
reminiscent of the pre-1994 period when vulnerable groups were severely harassed. Many citizens had their human rights violated by the security agencies including SAPS and the SANDF. An association between COVID-19 and criminality has been recorded where members of the police were arrested for committing horrendous crimes during the lockdown period, substantially increasing gender-based violence.

The centralisation of power by the state on providing humanitarian assistance to indigent communities has increased bureaucracy and fragmentation, as well as the frustrations of civil society groups who have been trying to assist needy communities by providing them with basic necessities. The humanitarian assistance offered by government, civil society groups and businesses has been marred by the interference of the ruling party's councillors and by distributing food parcels based on political allegiance.

This article touched on a host of dimensions that need to be tested empirically by future researchers by conducting an in-depth exploration using a mixed-methods approach in COVID-19 hotspots (mostly industrialised cities in South Africa). Although this study has methodological limitations as it is mostly a reflection study, it cannot be limited to the borders of South Africa as the impact of the coronavirus on the designated groups living in informal settlements is severe.

\section{Acknowledgements Competing interests}

The authors declare that they have no financial or personal relationships that may have inappropriately influenced them in writing this article.

\section{Authors' contributions}

B.N. and E.M. both contributed equally to this work.

\section{Ethical considerations}

This article followed all ethical standards for research without direct contact with human or animal subjects.

\section{Funding information}

This research received no specific grant from any funding agency in public, commercial or not-for-profit sectors.

\section{Data availability}

Data sharing is not applicable to this article as no new data were created or analysed in this study.

\section{Disclaimer}

The views and opinions expressed in this article are those of the authors and do not necessarily reflect the official policy or position of any affiliated agency of the authors.

\section{References}

African Union, 2020, Impact of the coronavirus (COVID-19) on the African economy viewed 12 April 2020, from https://www.tralac.org/documents/resources/covid19/3218-impact-of-the-coronavirus-covid-19-on-the-african-economy-africanunion-report-april-2020/file.html

Ahmad, M.M., n.d., The COVID-19 outbreak: A testing time for NGOs in Bangladesh, viewed May 2020, from https://www.e-ir.info/2020/05/06/the-covid-19outbreak-a-testing-time-for-ngos-in-bangladesh/

Al Jazeera, 2020, UN raises alarm about police brutality in COVID-19 lockdowns, viewed 12 April 2020, from https://www.aljazeera.com/news/2020/04/raisesalarm-police-brutality-covid-19-lockdowns-200428070216771.html

Austrian, K., Pinchoff, J., Tidwell, J.B., White, C., Abuya, T., Kangwana, B. et al., 2020 COVID-19-related knowledge, attitudes, practices and needs of households in informal settlements in Nairobi, Kenya, SSRN, viewed 27 June 2020, from https:// ssrn.com/abstract $=3576785$

Barnard, D., 2020, 'COVID-19 in South Africa - An overview of the NGO funding situation and fundraising efforts', SANET, 22 April, viewed 12 March 2021, from http://www.ngopulse.org/blog/2020/04/22/covid-19-south-africa-overviewnttp://wwW.ngopulse.org/blog/2020/04/22/cc

Braun, V. \& Clarke, V., 2006, 'Using thematic analysis in psychology', Qualitative ResearchinPsychology3(2),77-101.https://doi.org/10.1191/1478088706qp063oa

Breakfast, S., 2020, 'Watch: More lockdown looting in Cape Town [video]', The South African, April 14, viewed 15 April 2020, from https://www.thesouthafrican.com/ news/watch-more-lockdown-looting-in-cape-town-video/

Brown, F.Z., Brechenmacher, S. \& Carothers, T., 2020, How will the coronavirus reshape democracy and governance globally? Carnegie Endowment for International Peace, viewed 05 May 2020, from https://carnegieendowment. org/2020/04/06/how-will-coronavirus-reshape-democracy-and-governanceglobally-pub-81470

Bryman, A., 2014, Samhällsvetenskapliga metoder [Social science methods], Liber, Stockholm

Burke, J., 2020, 'South African police fire rubber bullets at shoppers amid lockdown', The Guardian, March 28, viewed 29 March 2020, from https://www.theguardian. $\mathrm{com} /$ world/2020/mar/28/south-africa-police-rubber-bullets-shoppers-covid-19lockdown

Calderon, C., Kambou, G., Djiofack, C.Z., Kubota, M., Korman, V. \& Canales, C.C., 2020, 'An analysis of Issues shaping Africa's economic future', Africa's Pulse, No. 21, Spring 2020, An analysis of issues shaping Africa's economic future, World Bank, Washington, viewed 11 April 2020, from https://openknowledge.worldbank.org/ handle/10986/33541

Centre for Risk Analysis, 2020, 'Fallout: Covid-19 and the economy', Macro Review, April 30, pp. 1-2.

City Press, 2020, 'Councillors accused of looting food parcels meant for the poor, April 19', viewed 08 October 2021, from https://www.news24.com/citypress/News/ councillors-accused-of-looting-food-parcels-meant-for-the-poor-20200419

Corburn, J., Vlahov, D., Mberu, B., Riley, L., Caiaffa, W.T., Rashid, S.F. et al., 2020, 'Slum health: Arresting COVID-19 and improving well-being in urban informal settlements', Journal of Urban Health 97, 348-357. https://doi.org/10.1007/ settlements', Journal

Corruption Watch, 2020, Govt covid-19 economic response inadequate, punitive, May 05, viewed 15 May 2020, from https://www.corruptionwatch.org.za/govt-covid19-economic-response-inadequate-punitive/

Davis, R., 2020a, 'How red tape is hampering the hungry from receiving food in South Africa', Daily Maverick, May 05, viewed 18 May 2020, from https://www. dailymaverick.co.za/article/2020-05-05-how-red-tape-is-hampering-the-hungryfrom-receiving-food-in-south-africa/

Davis, R., 2020b, 'What's really behind government regulations requiring food parcel donations to be handed over to local municipalities?', May 05, viewed 10 October 2020, from https://www.capetalk.co.za/articles/382754/has-governmentcreated-a-monopoly-on-food-distribution-in-order-to-gain-votes

Dlamini, P., 2020, 'Councillor accused of meddling in food parcels distribution', Sowetan Live, May 18, viewed 18 May 2020, from https://www.sowetanlive.co. za/news/south-africa/2020-05-18-councillor-accused-of-meddling-in-foodparcels-distribution/

DW, 2021, In numbers: DW's coverage on COVID-19 in India, viewed 08 March 2021 from https://www.dw.com/en/in-numbers-dws-coverage-on-covid-19-in-india/ a-58026921.

eNCA, 2020, '250,000 food parcels to be distributed during lockdown: Ramaphosa', eNCA, April 02, viewed n.d., from https://www.enca.com/news/250000-foodparcels-be-delivered-during-lockdown-ramaphosa

Engineering News, 2020, 'The South African water crisis persists', Engineering News, March 23, viewed n.d., from https://m.engineeringnews.co.za/article/thesouth-african-water-crisis-persists-2020-03-23

Evans, J., 2020, 'Sanef sounds alarm over the treatment of the media in Cape Town', News 24, April 08, viewed 09 April 2020, from https://www.news24.com/ SouthAfrica/News/sanef-sounds-alarm-over-the-treatment-of-the-media-incape-town-20200408

Favas, C., Checchi, F. \& Waldman, R.J., 2020, Guidance for the prevention of COVID-19 infections among high-risk individuals in urban settings, London School of Hygiene and Tropical Medicine, London.

Francis, D. \& Webster, E., 2019, 'Poverty and inequality in South Africa: Critical reflections', Development Southern Africa 36(6), 788-802. https://doi.org/10.108 0/0376835X.2019.1666703 
Githahu, M., 2020, 'Stats SA: 67.7\% worried about country's post COVID-19 future', Cape Argus, 24 May, viewed n.d., from https:/www.iol.co za/capeargus/news/ stats-sa-677-worried-about-countrys-post-covid-19-future-48452287

Hall, K., 2019, Child-only households: Statistics on children in South Africa, University of Cape Town, viewed 12 June 2020, from http://www.childrencount.uct.ac.za/ indicator. php?domain $=1$ \&indicator $=17$

High Court of South Africa (Gauteng Division Pretoria), 2020, Case No: 21542/2020, viewed 19 August 2021, from http://www.saflii.org.za/za/cases/ZAGPPHC/2020/280.pdf

Imray, G., 2020, 'Gangs deliver food in poor Cape Town area amid lockdown', Associated Press, May 18, viewed 18 May 2020, from http://www.statssa.gov. $\mathrm{za} /$ ?cat $=22$

Jarvis, C.I., Zan Vandvoort, K., Gimma, A., Prem, K., CMMID Working Group, Klepac, P. et al., 2020, 'Quantifying the impact of physical distance measures on the transmission of COVID-19 in the UK', BMC Medicine 18, 124. https://doi. org/10.1186/s12916-020-01597-8

Lilford, R.J., Oyebode, O., Satterthwaite, D., Melendez-Torres, G.J., Chen, Y.-F., Mberu, B. et al., 2017, 'Improving the health and welfare of people who live in slums', Lancet 389(10068), 559-570. https://doi.org/10.1016/S01406736(16)31848-7

Macarthy, J.M., Frediani, A.A., Kamara, S.F. \& Morgado, M., 2017, 'Exploring the role of empowerment in urban humanitarian responses in Freetown' IIED Working Paper, viewed 14 July 2020, from https://pubs.iied.org/pdfs/ 10845IIED.pdf

Mahlati, Z., 2020, 'People in five informal settlements to be relocated as Covid-19 concerns grow', Political Bureau, April 06, viewed 18 May 2020, from https://www.iol.co.za/news/south-africa/western-cape/people-infive-informal-settlements-to-be-relocated-as-covid-19-concerns-grow-46342074

Mayosi, B.M. \& Benatar, S.R., 2014, 'Health and health care in South Africa - 20 years after Mandela', The New England Journal of Medicine 371(14), 1344-1353. https://doi.org/10.1056/NEJMsr1405012

News24, 2020, 'Covid-19: UN Human Rights office concerned by excessive force, death reports during SA lockdown', April 28, viewed 28 April 2020, from https:// www.news24.com/SouthAfrica/News/un-human-rights-office-highlights-toxic lockdown-culture-in-sa-20200428

Ngamlana, N.Z., 2020, 'Food parcel plan assumed councilors have best interests of their people at heart', Sunday Independent, May 24, p. 6.

NGO Pulse, 2020, COVID-19 in South Africa-An overview of the NGO funding situation and fundraising efforts, viewed 08 May 2020, from http://www.ngopulse.org/ blog/2020/04/22/covid-19-south-africa\%E2\%80\%93-overview-ngo-fundingsituation-and-fundraising-efforts

National Institute of Communicable Diseases (NICD), 2020, First case of COVID-19 reported in South Africa, March 05, viewed 08 October 2021, from https://www. nicd.ac.za/first-case-of-covid-19-coronavirus-reported-in-sa/

Nyathi, A., 2020, 'Ipid investigates after 8 deaths recorded since lockdown', Eye Witness News, viewed 06 April 2020, from https://ewn.co.za/2020/04/03/ipidinvestigates-after-8-deaths-recorded-since-lockdown

Parker, A., Karamchand, S., Schrueder, N., Lahri, S., Rabie, H., Aucamp, A. et al. 2020 , 'Leadership and early strategic response to the SARS-CoV-2 pandemic at a COVID-19 designated hospital in South Africa', South African Medical Journal 10(6), 463-465. https://doi.org/10.7196/SAMJ.2020v110i6.14809

Parliamentary Monitoring Group, 2020, COVID-19 NGO food distribution: SRD R350 grant with Ministry, Social Development, May 29, viewed 15 June 2020, from hrttps://pmg.org.za/committee-meeting/30339/

Pietermaritzburg Economic Justice and Dignity, 2018, Household affordability index 2018, viewed 08 April 2020, from https://pmbejd.org.za/wp-content/uploads/ 2018/12/December-2018-Household-Affordability-Index-PMBEJD.pdf

Pietermaritzburg Economic Justice and Dignity, 2019, Household affordability index 2018, viewed 10 April 2020, from https://pmbejd.org.za/index.php/ household-affordability-index/
Pietermarmaritzburg Economic Justice and Dignity, 2020, Household affordability index 2020, December 16, 2020, viewed 03 April 2021, from https://pmbejd org. za/wp-content/uploads/2020/12/December-2020-Household-Affordabilityza/wp-content/uploads/2020
Index-PMBEJD_16122020.pdf

Pietermaritzburg Economic Justice and Dignity, 2021a, Household accountability index viewed 06 June 2021, from https://pmbejd.org.za/wp-content/uploads/2021/04/ April-2021-Household-Affordability-Index-PMBEJD_29042021.pdf

Pietermaritzburg Economic Justice and Dignity, 2021b, viewed 04 June 2021, https:// pmbejd.org.za/wp-content/uploads/2021/05/May-2021-HouseholdAffordability-Index-PMBEJD 26052021.pdf

Pillay, N., 2021, SA must return to its commitment to human rights values accreditation, City Press, May 23, viewed 04 April 2021, from https://www.news24.com/ citypress/voices/judge-navi-pillay-sa-must-return-to-its-commitment-to-humanrights-values-20210523

Plagerson, S. \& Mthembu, S., 2019, Poverty, inequality and social exclusion in South Africa: A systematic assessment of key policies, strategies and flagship programmes, Center for Social Development in Africa, Johannesburg viewed 08 April 2020, from https://www.uj.ac.za/faculties/humanities/csda/Documents/ NDA-Poverty-inequality-and-social-exclusion.\%2012.2.2020.pdf

Plecher, H., 2020, South Africa: Unemployment rate from 1999 to 2020, viewed 08 October 2021, from https://www.statista.com/statistics/370516/unemploymentrate-in-south-africa/

Schmidt, T., Cloete, A., Davids, A., Makola, L., Zondi, N. \& Jantjies, M., 2020, 'Myths, misconceptions, othering and stigmatizing responses to Covid-19 in South Africa: A rapid qualitative assessment', PLoS one 15(12), e0244420. https://doi. org/10.1371/journal.pone. 0244420

Singapore Department of Health, 2020, Update on COVID-19 situation viewed 08 October 2021, from https://twitter.com/sporeMOH/status/14457 76876505481228

Star Advertiser, 2020, 'South Africa's lockdown effective, but some problems emerge', April 13, viewed 13 April 2020, from https://www.staradvertiser.com/2020/04/13/ breaking-news/south-africas-lockdown-effective-but-some-problems-emerge/

Stats South Africa, 2021a, Category archives: Food security and hunger, viewed 22 May 2021, from http://www.statssa.gov.za/?cat=28

Stats South Africa, 2021b, Quarterly Labour Force Survey Quarter 1: 2021, viewed 04 June 2021, from http://www.statssa.gov.za/publications/P0211/P02111stQuarter2021.pdf

Studies on Poverty and Inequality Institute, 2017, 'Adequate housing in South Africa', SPII Working Paper, No. 16, September 2017, p. 33, viewed 21 August 2020, from http://www.spii.org.za/wp-content/uploads/2018/02/Right-to-Housing_2017.pdf

Talisuna, A.O., Okiro, E.A., Yahaya, A.A., Stephen, M., Bonkoungou, B., Musa, E.O. et al., 2019, 'Spatial and temporal distribution of infectious disease epidemics, disasters and other potential public health emergencies in the World Health Organisation Africa region, 2016-2018', Globalization and Health 16(1), 9. https:// doi.org/10.1186/s12992-019-0540-4

UN-Habitat, 2007, Twenty first session of the governing council, viewed 08 April 2020, from www.unhabitat.org

World Bank, 2018, The World Bank in South Africa, viewed 08 June 2020, from https:// www.worldbank.org/en/country/southafrica/overview

World Bank in Africa, 2020, COVID-19 (coronavirus) response, viewed 10 May 2020, from https://www.worldbank.org/en/region/afr/coronavirus

World Health Organization, 2020a, -nCoV is an emergency of international concern, World Health Organization, Geneva.

World Health Organization, 2020b, Responding to community spread of COVID-19: Interim guidance, March 07, No. WHO/COVID-19/Community Transmission/2020.1, World Health Organization, Geneva.

World Health Organization, 2020c, WHO announces COVID-19 a pandemic, viewed 20 April 2020, from http://www.euro.who.int/en/health-topics/health-emergencies/ coronavirus-covid-19/news/news/2020/3/who-announces-covid-19-outbreak-apandemic 